\title{
Moose Habitat Management and Timber Management Planning: Three Case Studies
}

\author{
by \\ D. Payne', J. McNicol'², G. Eason ${ }^{3}$, D. Abraham ${ }^{4}$
}

\section{Introduction}

The management of the forest resources in Ontario is goverened primarily by the Crown Timber Act RSO (1980) which was enacted over a century ago. Provision was made in 1952 for the Minister of the Department of Lands and Forests to "direct the marking of trees to be left standing ... for the purpose of ... watershed protection (and) game preserves or shelter ...." From this legal base, biologists with the now Ministry of Natural Resources (MNR) have been endeavoring to protect fish and wildlife values in Ontario for the past 35 years.

Studies have established that in winter, moose (Alces alces) prefer areas rich in browse interspersed with stands of mature cover (Le Resche et al. 1974, Peek et al. 1976, Hamilton and Drysdale 1975, McNicol and Gilbert 1980). The interspersion of mature or semi-mature coniferous, deciduous, or mixed wood stands creates a large amount of edge habitat, i.e., cover and browse in close proximity. Ontario's Moose Habitat Mangement Guidelines, introduced in 1978, are based on such studies and state that in the boreal forest "potentially large clear cuts that would not allow moose to be within approximately $200 \mathrm{~m}(650 \mathrm{ft})$ of suitable shelter should be broken into smaller cuts." Effective application of these guidelines was assisted in 1980 by the introduction of two key documents: 1) the Strategic Land Use Plan (SLUP)

1 Ontario Ministry of Natural Resources (MNR), Cochrane, Ontario.

2MNR, Thunder Bay, Ontario

3 MNR, Wawa, Ontario.

${ }^{4} \mathrm{MNR}$, Cochrane, Ontario. which assigned moose production and harvest targets across northern Ontario, and 2) the Moose Habitat Management Policy. This latter document said in part that "wildlife managers will work closely with forest managers to produce moose habitat in the northern forest regions ..." through the production of "irregular shaped cuts, scattered residual patches, and a high diversity of age classes and species stands..." The policy also recognized that "not all areas can be managed to maximize both timber and wildlife production, and compromises are a vital part of the management process."

\section{Forest Management Planning}

The forest management planning process for company licensed areas in Ontario has three stages. First, the 20-year plan prepared by the company outlines broad objectives, describes the planning area, provides maps showing proposed cutting areas, calculates the annual allowable cut $(A A C)$, and offers silvicultural prescriptions. A section on "Other Forest Uses", generally written by MNR, identifies fish and wildlife concerns in the area (e.g., early winter concentration areas for moose, or sensitive fish spawning grounds). Second, the Operating Plan covers a 5-year period and details how the forest will be cut and regenerated in a particular working circle. The locations of proposed roads, which stands will be cut and when, and what regeneration methods will be used are indicated at this point. This is the stage at which the company must specify how their operations will accommodate concerns identified by MNR in the 20 -year plan. When negotiations have resulted in a prescription acceptable to both MNR and the company, it is written into the Operating Plan. 
There are a number of cutting patterns that can contribute to improved moose habitat and natural regeneration of the harvested area. These include: group seed tree areas, alternate block cuts, alternate strip cuts, and linear (waterway) reserves. Each pattern results in the dispersion of uncut timber through the harvested area, thereby creating valuable edge habitat.

This paper presents three examples of how timber harvesting practices were modified in areas of high moose density. They are not meant to be examples of exemplary moose habitat management, but real cases demonstrating the planning process, how problems developed and what lessons were learned. The effectiveness of forest harvesting modifications to protect moose habitat is suggested by the results. Firm conclusions cannot be drawn, however, since rigorous experimental designs were not followed.

\section{Case Study 1: Three Island Lake - Thunder Bay District}

Three Island Lake is located approximately $145 \mathrm{~km}$ northwest of Thunder Bay, Ontario, within MNR's Northcentral Region. The study area soils are composed primarily of gently rolling sandy loams supporting mature to over-mature jack pine (Pinus banksiana) and upland black spruce (Picea mariana) characteristic of the boreal forest (Rowe 1972) (Table 1). Interspersed throughout are poorly drained areas supporting lowland blackspruce and numerous lakes and rivers (Fig. 1).

The study area is part of a $25 \mathrm{~km}^{2}(10 \times 2.5 \mathrm{~km})$ plot over which area surveys for moose were flown in 1976 and 1979. Moose densities there were higher than average for the general region. In 1980, the Great Lakes Forest Products Company (GLFP) of Thunder Bay made it known that cutting was proposed for the area. In an effort to ensure that post-cut habitat would sustain a comparable number of moose, MNR requested modifications to the company's 1980-1985 Operating Plan. A $50 \%$ cut and leave (i.e., alternate block) pattern was stipulated for the area around Three Island Lake and north of Pistol and Bullet Lakes (see Fig. 1). The logging company was given the flexibility to arrange the cut in a manner most economical for it.

To determine whether modified cutting affected the way moose used the study area, it was subdivided. Areas $A$ and $C$ were the blocks identified for modified cutting. Area B was clearcut without any restrictions and served as a control block (Fig. 2).

Data describing habitat types and moose densities were digitized using Lakehead University's geographic information

Table 1. Characteristics of the forest at Three Island Lake.

Total study area

1357 ha

Productive forest

1101 ha (81.1 of study area)

Species breakdown

Spruce (Picea mariana)

Jack pine (Pinus banksiana)

Balsam fir (Abies balsamea)

White birch (Betula papyrifera)

850 ha ( $77.2 \%)$

162 ha $(14.7 \%)$

33 ha ( $3.0 \%)$

$\frac{56 \text { ha }(5.1 \%)}{100.0 \%}$

Merchantable conifer available

1015 ha ( $92 \%$ of productive forest)

65500 cords

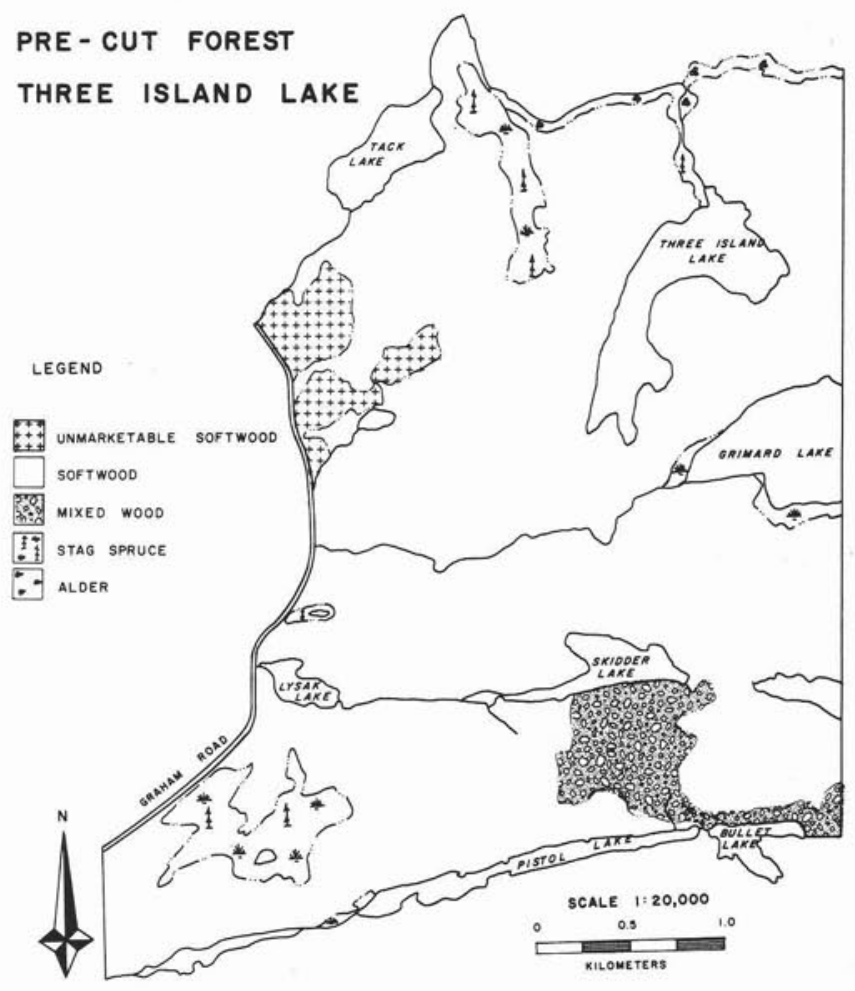

Figure 1. The pre-cut forest at Three Island Lake, Thunder Bay.

system (CARIS). Patterns of habitat (including edge) used by moose were then analysed on a use-availability basis (Neu et al. 1974). Significance was defined at the $P<0.05$ level.

\section{Results and Discussion}

When the Three Island Lake study area was cut, GLFP was six years into its 20-year Forest Management Plan covering the period 1975-1995. An Operating Plan (19801985), approved by MNR, should have been returned to the company by 1979 , before it built roads into the 1980 cutting areas. The company, however, submitted its proposed Operating Plan late and MNR's review and input were not completed until 1981. When the company received their 1980 Annual Plan back from MNR with the modified cut requirements in the Three Island Lake area, they objected for a number of reasons. First, the company had built roads into the area in 1979 without knowledge that substantial modification to their proposed cut would be requested at the annual plan stage. These roads would now provide access to reduced timber volumes and additional costs were projected for setting out the boundaries for leave blocks (Table 2). Second, moose habitat concerns were not commonly identified in the Three Island Lake area because moose inventory information indicated generally low densities there. Thus, the company was unconvinced of the need for moose habitat management in the area. Despite these early objections, however, negotiations between the company and MNR resulted in an agreement to block cut the prescribed stands.

Moose habitat management through the forest management planning process requires follow-up and assessment to determine whether the prescription to maintain or improve moose habitat was effective. Two aerial surveys for moose flown in 1984 and 1985 over the same plot covered in 1976 and 1979 showed that moose densities had roughly 


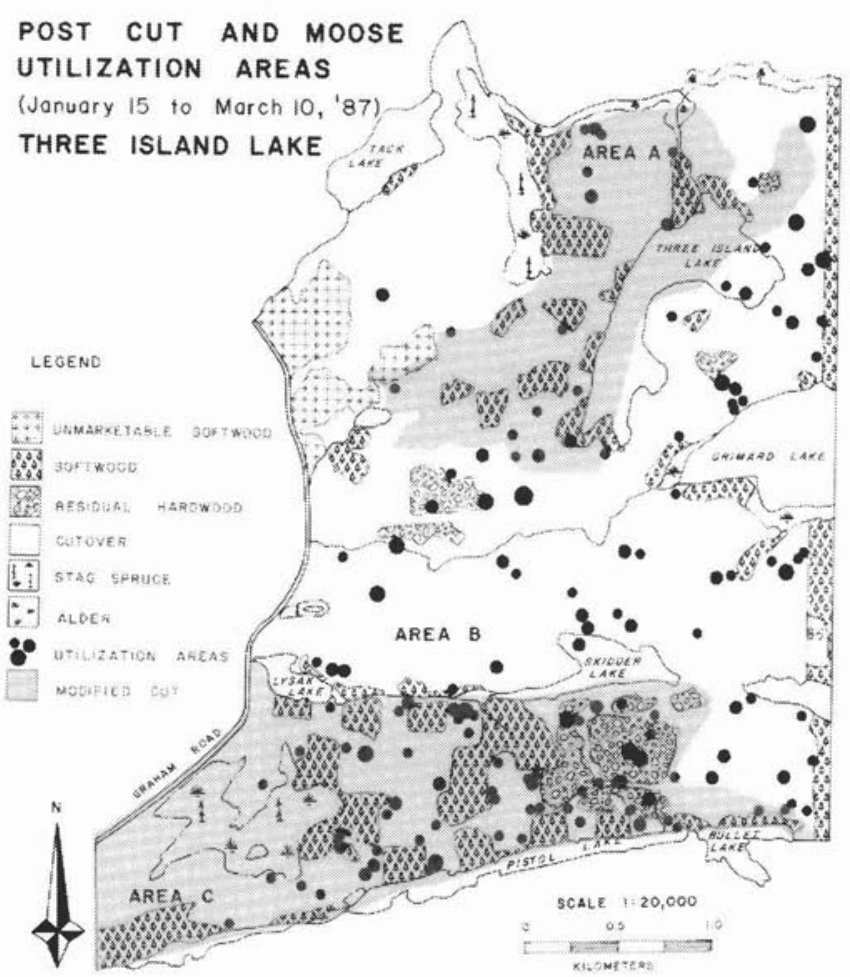

Figure 2. The post-cut forest at Three Island Lake, Thunder Bay. Modified cutting was done in Areas A and C. Area B was clear cut in the usual way. Patterns of habitat use by moose are also shown.

doubled since cutting. Five additional flights were made over the area from January to March 1987. Several factors in addition to modified cutting can help explain this increase. First, hunting has been largely prohibited in the area after cutting and second, there is a large area of uncut forest to the east (under another company's license). It is impossible to determine the relative importance of these three factors in increasing moose densities. However, we can examine whether areas cut in a modified way were used more heavily by moose than clearcut areas.

Area $\mathrm{C}$, the most southerly modified cut, had over twice the level of moose activity on its cutover portions between

Table 2. Summary of cut and leave volumes and costs (1987\$) absorbed by Great Lakes Forest Products Company at Three Island Lake.

First cut

yield 320 ha at 69 cords/ha

left 122 ha at 69 cords/ha

22120 cords

8400 cords

increased road and layout costs

additional cost/harvested cord

$\$ 9800.00$

$\$ 0.44$

Second cut (projected costs)

road reconstruction and layout costs (seed tree plots)

$\$ 14200.00$

volume to be harvested

additional cost/harvested cord

7700 cords $\$ 1.84$

Blowdown losses

700 cords ( $8 \%$ of remaining timber)

$\$ 7000$ in stumpage fees lost to the Crown
January and March of 1987 than did either Areas A or B (Table 3). This area provided at least 38\% more edge and at least $65 \%$ more residual cover within the cutover than areas $A$ or B. Twenty-eight percent $(28 \%)$ of the residual cover in area C consisted of partially cut mixed-wood stands (i.e., residual hardwood). Such areas generally support an abundance and diversity of browse mixed with deciduous and coniferous tree species at various stages of maturity - good moose habitat at this time of year (McNicol and Gilbert 1980). Moose use these residual mixed-wood stands more than expected in areas $B$ and $C(P<0.05)$.

Surprisingly, the cutover habitats in all three areas were used more than expected. Unhunted moose populations tend to use higher proportions of open cutover (i.e., further from cover) than do hunted ones (McNicol and Gilbert 1980). Also, when snow depth and/or consistency does not limit their movement, moose will venture further from cover to browse (Hamilton and Drysdale 1975). When surveys were flown (January to March 1987), snow depth averaged only $31 \mathrm{~cm}$ with little crusting and presented no impediment to moose movement. These conditions may also explain why the conifer-cutover edge was used less than expected in all three areas. It is also sometimes difficult to see moose tracks through dense conifer canopies and so at least some moose activity in this habitat type could have been missed during surveys.

Area C, with $33 \%$ residual cover, was more heavily used by moose than Area $A$ which remained $20 \%$-covered after cutting. Modified cutting in Area A seems to have failed to maintain moose numbers. Prior to cutting, the forester for GLFP reported little sign of moose in Area A during pre-cut ground work. It is possible that most of the moose seen in the study area during surveys were in the Area $C$ rather than evenly distributed throughout the plot. Finally, in Area B, the clearcut block, retention of mature coniferous cover adjacent to the residual hardwood stands probably would have been more effective habitat management.

Modified cutting in Area $\mathrm{C}$ has proven beneficial from a forest management perspective as well. Natural regeneration after scarification in this location has been good whereas in Area $A$ it has only been fair.

\section{Case Study 2: Bragg Township - Cochrane District}

Bragg Township lies approximately $56 \mathrm{~km}$ northeast of Cochrane, Ontario, within MNR's Northern Region. The study area is part of the "Iroquois Falls Forest" Forest Management Agreement (FMA) area operated by Abitibi-Price Inc. of Iroquois Falls. It is located in the westerly portion of Bragg Township and the forest is composed largely of conifer (spruce, balsam [Abies balsamea] or jack pine) and mixed

Table 3. Summary of moose densities (Jan. to March 1987) and post-cut characteristics of subareas $A, B$ and $C$ at Three Island Lake.

\begin{tabular}{lcccc}
\hline Area & $\begin{array}{c}\text { Total } \\
\text { area } \\
\text { (ha) }\end{array}$ & $\begin{array}{c}\text { Residual } \\
\text { cover } \\
\text { (\%) }\end{array}$ & $\begin{array}{c}\text { \% of } \\
\text { clearcut } \\
\text { utilized }\end{array}$ & $\begin{array}{c}\text { No. } \\
\text { track } \\
\text { aggregates/ha }\end{array}$ \\
\hline A (modified cut) & 200 & 20 & 0.4 & 0.085 \\
B (unmodified cut) & 817 & 14 & 0.4 & 0.069 \\
C (modified cut) & 340 & 33 & 1.1 & 0.177 \\
\hline
\end{tabular}

Aggregations of moose tracks indicated moose activity. 
wood stands. The study area was subdivided to produce a control area for comparisons: the southern section is the control area and the northern area the experimental area (i.e., modified cut) (Table 4).

Aerial surveys for moose conducted by MNR from 196079 showed consistently high densities relative to the Wildlife Management Unit mean of 0.03 moose $/ \mathrm{km}^{2}$. In the western third of Bragg Township, densities ranged from 0.08 to 0.37 moose $/ \mathrm{km}^{2}$. To maintain the status quo, MNR presented a proposal to Abitibi-Price in the spring of 1980 to modify their cutting plans for the area. Linear reserves, leave blocks (about 4 ha in area), and alternate strip cuts (in spruce lowlands) were recommended based on Ontario's Moose Habitat Management Guidelines (1978). Secondary to the purpose of habitat management was the need to examine how the application of standards for moose habitat management would work in the field. The concepts had never been tested in the Northern Region.

The study area was subdivided into a control area, which was clear cut in the usual manner, and an adjacent experimental area where cutting was modified as agreed. Habitat characteristics were compared using a ruggedness index (Racey 1981) and differences tested with the t-test. Significance was defined at the $\mathrm{P}<0.05$ level.

\section{Results and Discussion}

When Abitibi-Price was approached with MNR's moose habitat project, their staff were initially unsure of how to proceed. They had never participated in moose management before other than leaving stream and lake reserves. Of particular importance to the company was the fact that the area in question was the last large block of ground dry enough to allow summer access. The company needed this wood to keep its nearby operation viable. (Since 1980, equipment improvements have largely alleviated such operating restrictions). Other concerns included the added cost of modified harvesting (laying out the leave blocks, supervising cutting near their boundaries, and the loss of about $30000 \mathrm{~m}^{3}$ of softwood) (Table 5). In addition the mathematical block layout proposed by the MNR gave no consideration to operational constraints (e.g., topography, unmerchantable timber, etc. ...), and proposed restrictions on road building.

After several meetings, negotiations between MNR and the company resulted in agreement to harvest the Bragg Township study area in a modified manner and MNR agreed to absorb part of the layout costs. An Annual Plan acceptable to all parties was completed in December 1980. Cutting began in the spring of 1982 and was completed during the 1985/86 season.

\begin{tabular}{lcccc}
\hline \multicolumn{4}{l}{ Table 4. Characteristics of the forest at Bragg Township. } \\
\hline $\begin{array}{l}\text { Dominant } \\
\text { Cover type }\end{array}$ & $\begin{array}{c}\text { Experimental Area } \\
\text { ha }\end{array}$ & $\begin{array}{c}\text { Control Area } \\
\text { (\%) }\end{array}$ & ha & $(\%)$ \\
\hline Conifer & 1865 & $(47)$ & 1632 & $(42)$ \\
Hardwood & 72 & $(2)$ & 68 & $(2)$ \\
Mixedwood & 1520 & $(38)$ & 1669 & $(43)$ \\
Water & 368 & $(10)$ & 123 & $(3)$ \\
Other $^{2}$ & 129 & $(3)$ & 376 & $(10)$ \\
\hline
\end{tabular}

Conifer type defined as $71 \%$ black spruce, balsam fir or jack pine

Hardwood type defined as $71 \%$ poplar (Populus tremuloides) or white birch

Mixed wood type defined as $30 \%$ conifer or hardwood

Including grasslands and alder (Alnus spp.)
Table 5. Summary of $\operatorname{costs}^{1}$ absorbed by government and Abitibi-Price on the Experimental Area of Bragg Township.

\begin{tabular}{lll}
\hline & Cost/ha & Total \\
\hline Road construction/mtce & $\$ 346.00$ & $\$ 34284$ \\
Block layout & $\$ 7.00$ & $\$ 693$ \\
Total additional cost & $\$ 353.00$ & $\$ 34977$ \\
FMA road subsidy & $\$ 92.00$ & $\$ 9108$ \\
Net extra cost to company & $\$ 261.00$ & $\$ 25869$ \\
\hline
\end{tabular}

Added costs not quantified include those of crew relocation, hauling, silviculture, and los revenue in bypassed timber.

Aerial surveys for moose were made during the harvest period $(1982-86)$ to help assess whether the prescribed modifications were effective tools for habitat management. Three times the number of moose were observed using the experimental area compared with the control area (Table 6). Topographical features of the two areas do not differ (ruggedness test, $P<0.05$ ) and vegetation characteristics appear quite similar as well (Table 4). There is little difference between the clearcut control area and the experimental area in the proportion of wood left standing (Table $7 a$ \& b), despite the use of modified cutting. More important than the volume of residual wood is its dispersion which creates valuable edge habitat. This alone may explain the greater numbers of moose observed in the experimental area. Distance to cover has been demonstrated to be more important than the actual quality of the habitat (Clarke and Greenwood 1985). However, it is impossible to be conclusive regarding the potential benefits to moose of modified cutting because follow-up observations were made prior to the completion of cutting. Moose activity may have been influenced by as yet uncut areas nearby.

As part of the company's responsibility under the terms of its FMA, regeneration activities were undertaken in the harvested portions of the study area. Some natural regeneration should occur where cutting was modifed for moose habitat management due to the dispersion of the residual timber (residual patches act as seed reservoirs). Artificial regeneration is typically followed by aerial tending which involves the use of herbicides such as 2-4D or Vision to control competing vegetation while the newly planted trees become established. Unfortunately much browse was killed when the study area was sprayed, further masking the effects of modified harvesting on the moose of Bragg Township.

Table 6. Observed moose densities (excluding missed aggregates) in Bragg Township.

\begin{tabular}{lcc}
\hline Date & $\begin{array}{c}\text { Experimental area } \\
\left(\mathbf{m o o s e} / \mathbf{k m}^{2}\right)\end{array}$ & $\begin{array}{c}\text { Control area } \\
\left(\mathbf{m o o s e} / \mathbf{k m}^{2}\right)\end{array}$ \\
\hline Dec. 17, 1982 & 0.31 & 0.05 \\
Jan. 13, 1983 & 0.08 & 0.08 \\
Feb. 4, 1983 & 0.05 & 0 \\
Mar. 21, 1983 & 0 & 0 \\
Dec. 9, 1983 & 0.08 & 0.05 \\
Jan. 23, 1984 & 0.21 & 0.08 \\
Dec. 9, 1985 & 0.23 & 0.03 \\
Jan. 2, 1986 & 0.18 & 0 \\
Jan. 21, 1986 & 0.10 & 0 \\
Feb. 4, 1986 & 0.03 & 0.03 \\
Mar. 12, 1986 & 0.05 & 0.08 \\
Mean density & & \\
\hline
\end{tabular}




\begin{tabular}{|c|c|c|c|c|c|c|}
\hline Type & Reserve & $\begin{array}{l}\text { Leave } \\
\text { block }\end{array}$ & Bypass & $\begin{array}{c}\text { Block } \\
\text { cut }\end{array}$ & $\begin{array}{c}\text { Clear or } \\
\text { partial cut }\end{array}$ & Total \\
\hline Conifer & $\begin{array}{r}361 \\
(9)\end{array}$ & $\begin{array}{l}33 \\
(1)\end{array}$ & $\begin{array}{l}298 \\
(8)\end{array}$ & $\begin{array}{l}21 \\
(1)\end{array}$ & $\begin{array}{c}1152 \\
(29)\end{array}$ & $\begin{array}{r}1865 \\
(47)\end{array}$ \\
\hline Mixedwood & $\begin{array}{r}242 \\
(7)\end{array}$ & $\begin{array}{l}66 \\
(2)\end{array}$ & $\begin{array}{l}331 \\
(8)\end{array}$ & $\begin{array}{c}2 \\
(1)\end{array}$ & $\begin{array}{c}879 \\
(22)\end{array}$ & $\begin{array}{r}1520 \\
(39)\end{array}$ \\
\hline Hardwood & $\begin{array}{l}10 \\
(1)\end{array}$ & $\begin{array}{r}0 \\
(1)\end{array}$ & $\begin{array}{l}29 \\
(1)\end{array}$ & $\begin{array}{r}0 \\
(0)\end{array}$ & $\begin{array}{c}33 \\
(1)\end{array}$ & $\begin{array}{l}72 \\
(2)\end{array}$ \\
\hline Other & $\begin{array}{l}17 \\
(1)\end{array}$ & $\begin{array}{r}0 \\
(1)\end{array}$ & $\begin{array}{l}4491 \\
(11)\end{array}$ & $\begin{array}{r}1 \\
(1)\end{array}$ & $\begin{array}{c}30 \\
(1)\end{array}$ & $\begin{array}{l}497 \\
(12)\end{array}$ \\
\hline Total & $\begin{array}{l}630 \\
(16)\end{array}$ & $\begin{array}{l}99 \\
(3)\end{array}$ & $\begin{array}{c}1107 \\
(28)\end{array}$ & $\begin{array}{l}24 \\
(1)\end{array}$ & $\begin{array}{c}2094 \\
(53)\end{array}$ & $\begin{array}{l}3954 \\
(100)\end{array}$ \\
\hline
\end{tabular}

Includes water.

\section{Case Study 3: DREE Road - Wawa District}

The DREE Road study area is located near the town of Dubreuilville, within MNR's Northeastern Region. The area is $98 \mathrm{~km}^{2}$ of rolling to hilly terrain with many small lakes and streams and is $90 \%$ covered by typical southern upland boreal forest. The precut forest had a fairly even mixture of overmature conifer stands (mainly jack pine, with some black spruce), mixedwood stands, and hardwood stands (poplar [Populus tremuloides] and white birch [Betula papyrifera]).

The DREE Road area has been included in this series of case studies because it was harvested in a cut and leave pattern that approximates recommendations in the provincial moose habitat guidelines. Modified cutting was done as part of a road subsidy program for timber management to encourage the harvesting of overmature timber and promote natural regeneration in the area. Thus, this case study is not strictly comparable to the other two regarding the use of the Forest Management Planning Process to manage moose habitat in Ontario's forests. However, the effect of modified harvesting on the logging company can be examined and because moose inventories were made in the DREE Road area both before and after cutting some insight may be gained on the effect of modified cutting on moose densities there.

Cutting in the DREE Road study area began in 1984 and will continue until 1988. Approximately $39 \%$ of the forest area
( $3460 \mathrm{ha}$ ) and $47 \%$ of the conifer volume $\left(380000 \mathrm{~m}^{3}\right)$ is being harvested in 30 blocks averaging 115 ha each. Leave blocks are slightly larger but have a $28 \%$ lower conifer component than the cut blocks. About $5 \%$ of the leave area is protection forest. The second cut will remove most of the leave blocks and most of the remaining conifer volume in 5 to 10 years. Some of the cuts will be broken up in places by pockets of residual hardwood. Reserves, usually $60 \mathrm{~m}$ wide, were used less than if the area had been subjected to a continuous clearcut, but still amounted to 160 ha $(4.1 \%$ of the first cut).

Aerial surveys of the moose population area were conducted in 1982,1986, and 1987, and are planned for 1988 and 1989 . The 1982 survey may not be directly comparable with the 1986 and 1987 surveys because of its smaller area, later date, and poorer tracking conditions.

\section{Results and Discussion}

In 1982 the area was uncut and had no road access. In 1986 , there was a small amount of cutting ( $7 \%$ of forested area) and some roads. By 1987, there was moderate cutting ( $19 \%$ of the forested area) and many roads.

From 1982 to 1986 moose densities apparently increased, but the lower density data for 1982 are uncertain because of survey quality. From 1986 to 1987, moose

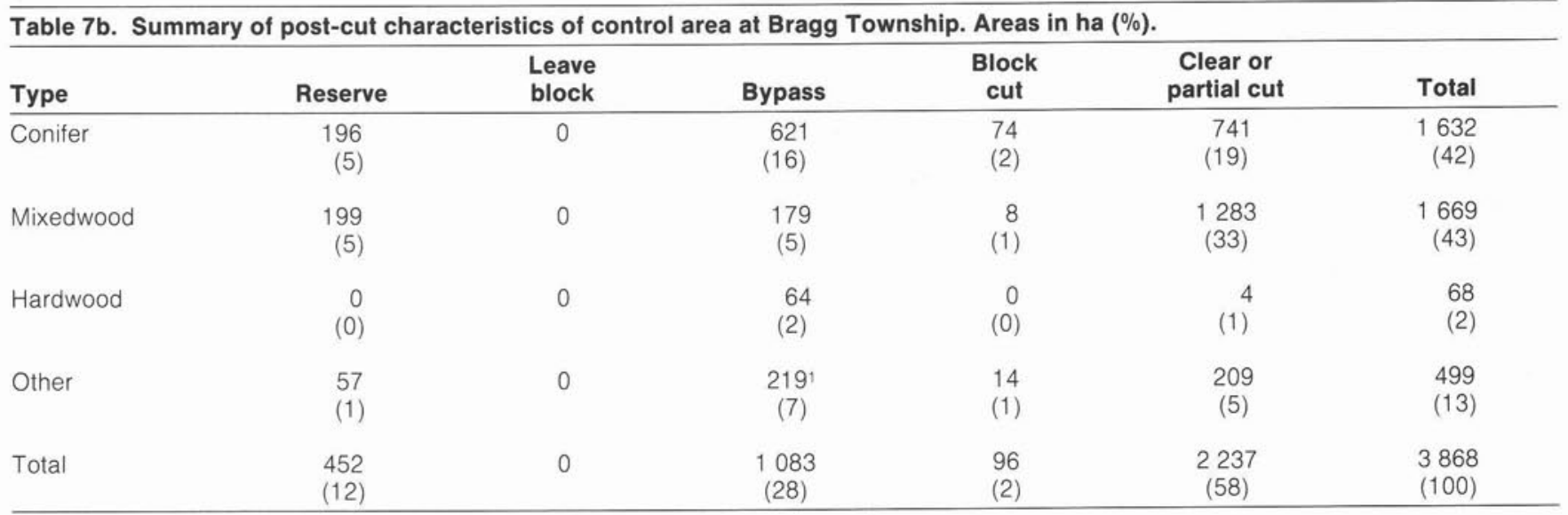

Includes water. 
densities appear to have declined from $0.45 / \mathrm{km}^{2}$ in 1986 to $0.24 / \mathrm{km}^{2}$ in 1987 . Hunting may be a factor in this decline as moose harvest estimates indicate that approximately 0.20 moose $/ \mathrm{km}^{2}$ were taken in 1986. During the fall of 1987 , additional controls were placed on hunting and early figures indicate that the population is responding. It is still too early to assess whether block cutting has benefited moose in this area. Preliminary results, however, suggest that the alternate block cuts may support more moose after hunting than continuous clearcuts. Densities in clearcut areas declined to approximately $0.1 \mathrm{moose} / \mathrm{km}^{2}$ after hunting (Eason 1985).

After the return cut, 5 to 10 years following the first cut, the block cut area will be very similar to a continuous clearcut. Winter habitat will be greatly reduced and the area will be even more susceptible to overhunting. A longer leave period (about 15 to 20 years) would allow the blocks cut during the first harvest to regenerate to the point where they might offer moderate cover for wintering moose. However, this could result in losses of timber as the original leave blocks become overmature.

At present, the main timber management objective of harvesting overmature wood is being achieved with the block cut pattern. However in future, block cutting may result in stands below rotation age being cut to retain leave blocks in overmature stands. This could result in substantial loss of timber from mortality in the overmature leave blocks and smaller volumes in the cut blocks below rotation age. This problem increases as the leave period increases.

The benefits of block cutting on forest regeneration are unclear. It is too early to assess the success of natural regeneration on the DREE Road study area. In fact, block cutting may have negative effects on regeneration by limiting the use of prescribed burns. Smaller blocks are more expensive and more difficult to burn than an equivalent area in a large block.

The impact of modifed havesting on the logging company in the DREE Road case study was similar to that found for Three Island Lake and Bragg Township. The company found that boundaries for the leave blocks had to be altered to accommodate topographic and other features (e.g., existing roads) on the site. Layout costs were higher as were those for road construction. It is worth noting that road costs will become more of a problem as FMA subsidies decline. Operating costs were higher as well because equipment had to be moved more often and more supervision of boundaries was required. In the future, timber production may be reduced if the harvest is allocated in immature stands in order to provide leave blocks in overmature stands and this will result in lower revenue for the company. On the positive side, the leave blocks reduce the need for lake and stream reserves which are typically required in areas that are clearcut.

Another dimension to the DREE Road case study is the presence of tourist lodges and outpost camps near the study area that require natural scenery, remoteness, and good fishing and hunting to attract clients. Logging operations are typically noisy, unsightly, and create extensive road networks. Lodge operators have indicated concern that block cutting will prolong noise (because of the return cut), produce roads that give local anglers and hunters access to lakes designated for tourists, and destroy the wilderness quality of their location.

These concerns were addressed as follows. To mitigate the visual impact of logging, it was agreed to leave skyline reserves around the lakes with tourist operations on them. It was agreed that block cutting would look much better from the air than clearcutting. The problem of logging and hauling noise was solved by scheduling the cutting of blocks near the tourism lakes for the winter. It was argued that the leave blocks would help buffer noise to some extent as well. Road locations were carefully planned to avoid creating access to lakes with tourist camps. Where access has occurred, road blocks (culvert removal or berming after logging and silviculture) and closure (using the Public Lands Act and a gate) have been successful in controlling summer access. However, winter access by snow machines has increased despite these efforts. To maintain good fishing on the tourism designated lakes, changes to the fishing regulations are being proposed. The number and quality of fishing opportunities near Dubreuilville are also being increased in an effort to take local fishing pressure away from the tourism lakes. Lodge owners are also concerned that extensive road access, characteristic of the block cut areas, may have reduced the local moose population more than continuous clearcutting. Furthermore, the need for a return cut serves to prolong access, thereby delaying the recovery of the moose population. In response to these concerns, experimental road closures are being tried as a protective measure.

On the other side of the debate are the local anglers and hunters, bear hunt outfitters, trappers, and the owners of motels, gas stations, and stores which depend on road access to fishing and hunting for part of their business. These users have objected to the restriction of vehicle access in some areas for the protection of remote lake tourism. The MNR has responded by limiting closures to a minimum number of secondary and tertiary roads.

The impact of a modified harvest on timber and moose habitat management, and on other users of the forest could not be assessed in the DREE Road case study. Further study is necessary to quantify the costs absorbed by the logging company and the tourist industry, and the net benefits to moose before conclusions can be drawn.

\section{Overview}

Problems were encountered during the planning process and in implementing moose habitat management at Three Island Lake and Bragg Township. Improving timing and communication was emphasized in the Three Island Lake study because most difficulties stemmed from late identification of wildlife concerns and MNR's late approval of the company's Annual Plan. It was recommended that the Annual Plan be made available to MNR for review, input and final approval at least a year prior to road building and cutting. The current planning process, involving a planning team composed of representatives from the logging company and the MNR, was just evolving when the Three Island Lake case study was being done. A very tight, formal planning schedule has now resulted which accommodates public reviews of the Plan at four specific stages. Twelve months after the team starts, they produce a finished Plan reviewed by the public, MNR, and the logging company. Early receipt of the company's maps indicating the areas for harvest is key to the success of this process. The planning team approach can also foster good communication and a good working rapport between MNR and the company.

A second problem identified in all three case studies is that modified harvesting is more expensive than traditional clearcutting. For companies operating on FMA's, higher road 
costs would be of less concern than for those working outside them. As for increased layout costs, MNR has shown willingness to negotiate by agreeing to absorb part of the layout costs in Bragg Township. Increased operating costs (i.e., moving equipment from block to block) can be partially offset by careful planning. At Three Island Lake, however, the company incurred the cost of moving operations off the study area altogether so it could harvest the additional 8400 cords it needed to fulfill its mill's volume commitment for the year. This situation may not always be avoidable through planning. The loss of wood, a concern identified in all three case studies, can be a temporary problem. The cut and leave modification involves returning in a specified number of years to cut the leave blocks if economically viable. Most permanent losses of wood occur due to blowdown and/or degradation of standing timber that has become overmature since the first cut, and the need to allocate harvest in immature stands so some mature and overmature stands can be left for moose habitat. Finally, the cost of regeneration was higher for block cut areas than for clearcuts because of the difficulty of dealing with small areas. This might be offset by some extent by better natural regeneration as noted at Three Island Lake.

Generally, the logging companies involved were cooperative and willing to spend time and money on moose habitat management. In the cases of Three Island Lake and Bragg Township, company staff did not initially appreciate the need for such projects or how logging and moose management could be achieved on the same site. Solid data on moose densities, patterns of habitat use, and moose response to logging operations will facilitate a better understanding of how habitat management and logging can coexist. To this end, case studies featuring rigorous experimental designs and pursued over the long term are needed to properly assess the impact of modified harvest techniques on moose. With this information, planning teams will be better able to negotiate successfully for improved moose habitat management in Ontario.

\section{Acknowledgements}

The authors would like to gratefully acknowledge the participation of both MNR and company foresters in the preparing of this summary. The following individuals prepared and summarized the forestry data: H. Hopper, G. Stanclick, P. Corbett, P. Street, Q. Day and G. MacGillivray. In addition, K. Wylie assisted in the preparation of the Three Island Lake study.

\section{References}

Clarke, T. and C. Greenwood. 1985. Moose utilization of modified harvest cuts in Northern Region. Ontario Ministry of Natural Resources. Unpublished Report.

Eason, G. 1985. Overharvest and recovery of moose in a recently logged area. Alces 21: 55-75.

Hamilton, G.D. and P.D. Drysdale. 1975. Effects of cutover width on browse utilization by moose. Proc. N. Amer. Moose Cont. Workshop 11: 5-26

Le Resche, R.E., R.H. Bishop and J.W. Coady. 1974. Distribution and habitats of moose in Alaska. Natur. Can. 101: 143-178.

McNicol, J.G. and F.F. Gilbert. 1980. Late winter use of upland and cutovers by moose. J. Wildl. Manage. 44: 363-371.

Neu, C.W., C.R. Byers and J.M. Peek. 1974. A technique for analysis of utilization - availability data. J. Wild. Manage. 38 : $541-545$

Peek, J.M., D.L. Urich and R.J. Mackie. 1976. Moose habitat selection and relationship to forest management in northeastern Minnesota. Wildl. Monogr. No. 48. 65 pp.

Racey, G. 1981. Moose habitat indexing system. Part 1: Physical features. Unpubl. manuscript.

Rowe, J.S. 1972. Forest Regions in Canada. Can. For. Serv., Dept. of the Environment, Ottawa. 172 pp. 